\title{
Modulation of secretion by the endoplasmic reticulum in mouse chromaffin cells
}

\author{
Ricardo Rigual, Mayte Montero, Alberto J. Rico, Jesús Prieto-Lloret, María Teresa Alonso and Javier Alvarez \\ Instituto de Biología y Genética Molecular (IBGM), Departamento de Bioquímica y Biología Molecular y Fisiología, \\ Facultad de Medicina, Universidad de Valladolid and Consejo Superior de Investigaciones Científicas (CSIC), \\ Ramón y Cajal, 7, E-47005 Valladolid, Spain
}

Keywords: adrenal gland, aequorin, $\mathrm{Ca}^{2+}, \mathrm{Ca}^{2+}$ channels, caffeine, catecholamine, ciclopiazonic acid, ryanodine, thapsigargin

\begin{abstract}
The endoplasmic reticulum (ER) has been suggested to modulate secretion either behaving as a $\mathrm{Ca}^{2+}$ sink or as a $\mathrm{Ca}^{2+}$ source in neuronal cells. Working as a $\mathrm{Ca}^{2+}$ sink, through $\mathrm{ER}^{2} \mathrm{Ca}^{2+}$ pumping, it may reduce secretion induced by different stimuli. Instead, working as a $\mathrm{Ca}^{2+}$ source through the $\mathrm{Ca}^{2+}$ induced $\mathrm{Ca}^{2+}$ release $(\mathrm{CICR})$ phenomenon, it may potentiate secretion triggered by activation of plasma membrane $\mathrm{Ca}^{2+}$ channels. We have previously demonstrated the presence of CICR in bovine chromaffin cells, but we now find that mouse chromaffin cells almost lack functional caffeine-sensitive ryanodine receptors in the $\mathrm{ER}$ and, consistently, no CICR from the ER could be observed. In addition, inhibition of ER $\mathrm{Ca}^{2+}$ pumping with ciclopiazonic acid or thapsigargin strongly stimulated high- $\mathrm{K}^{+}$-evoked catecholamine secretion and cytosolic $\left[\mathrm{Ca}^{2+}\right]\left(\left[\mathrm{Ca}^{2+}\right]_{c}\right)$ transients. Surprisingly, $5 \mathrm{mM}$ caffeine reduced high- $\mathrm{K}^{+}$-induced $\left[\mathrm{Ca}^{2+}\right]_{\mathrm{c}}$ peaks but considerably potentiated secretion induced by high- $\mathrm{K}^{+}$stimulation. However, this potentiation was insensitive to ryanodine and additive to that induced by emptying the $\mathrm{ER}$ of $\mathrm{Ca}^{2+}$ with thapsigargin, suggesting that it is unrelated to the activation of ryanodine receptors. We conclude that, in mouse chromaffin cells, CICR is not functional and the ER strongly inhibits secretion by acting as a damper of the $\left[\mathrm{Ca}^{2+}\right]_{\mathrm{c}}$ signal.
\end{abstract}

\section{Introduction}

$\mathrm{Ca}^{2+}$ binding to ryanodine receptors (RyR) present in the endoplasmic reticulum (ER) may lead to the opening of these receptors, triggering $\mathrm{Ca}^{2+}$ release into the cytosol (Berridge, 1998). This phenomenon, known as $\mathrm{Ca}^{2+}$ induced $\mathrm{Ca}^{2+}$ release (CICR), is a wellcharacterized mechanism in heart cells, but its presence and functional role in other excitable cells, in particular neuronal cells, is unclear. Three isoforms of RyR are expressed in mammalian tissues. RyR1 and RyR2 are expressed predominantly in sarcoplasmic reticulum of skeletal muscle and heart, respectively (Sutko \& Airey, 1996; Zucchi \& Ronca-Testoni, 1997), but all three RyR have been also found in brain (McPherson \& Campbell, 1993; Sorrentino \& Volpe, 1993; Giannini et al., 1995; Martin et al., 1998; Mori et al., 2000; Faure et al., 2001) and other tissues, including the adrenal gland (Giannini et al., 1995; Mackrill et al., 1997; Jiménez \& Hernández-Cruz, 2001). The presence of RyR in different neuronal tissues, together with the demonstration of a functional role of caffeine- or ryanodine-sensitive $\mathrm{Ca}^{2+}$ stores in neuronal $\mathrm{Ca}^{2+}$ transients or synaptic transmission (Peng, 1996; Smith \& Cunnane, 1996; Mothet et al., 1998; Narita et al., 1998, 2000; Llano et al., 2000; Emptage et al., 2001; Carter et al., 2002) has led to suggest an important role for CICR in $\mathrm{Ca}^{2+}$ signalling, $\mathrm{Ca}^{2+}$ homeostasis and activity-dependent synaptic plasticity in neurons (Rose \& Konnerth, 2001).

Correspondence: Javier Alvarez, as above.

E-mail: jalvarez@ibgm.uva.es

Received 27 May 2002, revised 25 July 2002, accepted 23 August 2002
Measuring CICR in small neuronal cells has proven elusive because of the difficulty of distinguishing $\mathrm{Ca}^{2+}$ release from $\mathrm{Ca}^{2+}$ entry when only cytosolic $\left[\mathrm{Ca}^{2+}\right]\left(\left[\mathrm{Ca}^{2+}\right]_{\mathrm{c}}\right)$ is monitored. In bovine chromaffin cells, we have shown unequivocally the presence of CICR by measuring directly the $\left[\mathrm{Ca}^{2+}\right]$ in the ER $\left(\left[\mathrm{Ca}^{2+}\right]_{\mathrm{ER}}\right)$. Stimulation with high- $\mathrm{K}^{+}$medium produced a large increase in $\left[\mathrm{Ca}^{2+}\right]_{\mathrm{c}}$ in parallel with a rapid decrease of $\left[\mathrm{Ca}^{2+}\right]_{\mathrm{ER}}$ mediated by RyR (Alonso et al., 1999). However, the importance of this phenomenon for catecholamine secretion is unclear. Capacitance measurements in bovine chromaffin cells have shown a depression in the secretory response after $\mathrm{ER} \mathrm{Ca}^{2+}$ depletion with thapsigargin (Mollard et al., 1995; Pan $\&$ Fox, 2000). In the same cells, measurements in cell populations have suggested that the ER could behave either as a $\mathrm{Ca}^{2+}$ source (enhancing secretion) when it was full or as a $\mathrm{Ca}^{2+}$ sink (reducing secretion) when it was fully emptied by caffeine (Lara et al., 1997). In contrast, it has been shown recently (Cuchillo-Ibáñez et al., 2002) that irreversible emptying of the ER with thapsigargin modifies little the secretory response induced by high- $\mathrm{K}^{+}$. Although most of these data suggest a role for the ER in the modulation of the secretory response, the precise mechanism(s) of this modulation remain obscure. We have used here mouse chromaffin cells to study this phenomenon and show that they behave in a very different way regarding the CICR phenomenon. They almost lack functional RyR in the ER and both the $\left[\mathrm{Ca}^{2+}\right]_{\mathrm{c}}$ increase and the secretory responses induced by high- $\mathrm{K}^{+}$were strongly potentiated by inhibiting ER $\mathrm{Ca}^{2+}$ pumping. Interestingly, the secretory response was also potentiated by low concentrations of caffeine, but this effect was unrelated to CICR, as it was insensitive to ryanodine and additive to that obtained after $\mathrm{ER} \mathrm{Ca}^{2+}$ depletion. 


\section{Materials and methods}

\section{Animal and surgical procedures}

Experiments were performed using adrenal medulla from mice of 68 weeks. Mice were anaesthetized with sodium pentobarbitone administered intraperitoneally $(60 \mathrm{mg} / \mathrm{kg}$ body weight). After a longitudinal incision in the abdomen, adrenal glands were removed and placed in a lucite chamber filled with ice cold Tyrode-bicarbonate solution (116 mM NaCl, $5 \mathrm{mM} \mathrm{KCl,} 2 \mathrm{mM} \mathrm{CaCl}_{2} ; 1.1 \mathrm{~mm} \mathrm{MgCl}_{2}$, $5 \mathrm{~mm}$ glucose, $23 \mathrm{~mm} \mathrm{NaHCO}_{3}$ ) equilibrated with $95 \% \mathrm{O}_{2}: 5 \% \mathrm{CO}_{2}$. Under a dissecting microscope, adrenal glands were gently decapsulated with fine forceps (Dumont $n^{\circ} 5$ ) and stored in fresh ice cold Tyrode until tissues were processed for measuring catecholamine content, catecholamine secretion or monitoring calcium levels in dissociated cells from primary tissue cultures using recombinant aequorin.

\section{Measurement of catecholamine content}

Adrenal medulla were homogenized (glass/glass) in ice-cold $(200 \mu \mathrm{L})$ perchloric acid $0.2 \mathrm{M}$ containing $0.01 \%$ EDTA and centrifuged $(10000 \times g$ for $10 \mathrm{~min})$. Aliquots from supernatant $(25 \mu \mathrm{L})$ were injected directly into a high-performance liquid chromatography-electrochemical detection (HPLC-ED) system. HPLC-ED system was composed of a Milton Roy CM 400 pump (Riviera, FL, USA), a Water c18 (particle size $4 \mu \mathrm{m}$ ) column, a Water U6K injector (Milford, MA, USA) and a Bioanalitical System (West Lafayette, IN, USA) LC-4 electrochemical detector (holding potential of $0.65 \mathrm{~V}$ ). Identification and quantification of endogenous content were performed against external standards (PeakSimple Chromatography Data System; SRI instruments, East Norwalk, CT, USA).

\section{Amperometric measurements of catecholamine secretion}

Adrenal medulla were incubated in a diluted enzymatic solution for $20 \mathrm{~min}$ at $37^{\circ} \mathrm{C}$ with gentle agitation in order to facilitate penetration of the carbon fibre electrode into the tissues. The diluted enzymatic Tyrode-bicarbonate solution equilibrated with $95 \% \mathrm{O}_{2}: 5 \% \mathrm{CO}_{2}$ contains collagenase $(0.1 \%$, Worthington type I, Lakewood, NJ, USA) and trypsin ( $0.01 \%$ Sigma grade IX). After washing in fresh ice-cold Tyrode, tissues previously subjected to the diluted enzymatic solution, were transferred to a thermostatized lucite recording chamber $\left(37^{\circ} \mathrm{C}\right.$, volume $\left.200 \mu \mathrm{L}\right)$ and superfused by gravity with Tyrode bicarbonate solution equilibrated with $20 \% \quad \mathrm{O}_{2}: 5 \%$ $\mathrm{CO}_{2}: 75 \% \mathrm{~N}_{2}(3-4 \mathrm{~mL} / \mathrm{min})$. The perfusion system had several lines and switching from one to another was made by an electronic valve system. Both saline reservoir bottles and the superfusion tube lines were immersed in a circulating water bath at $37{ }^{\circ} \mathrm{C}$.

Free catecholamines were measured using carbon fibre electrodes composed of a single 5- $\mu \mathrm{m}$ carbon fibre insulated, except for the tip, with a polyethylene tube (ProCFE, DAGAN Instruments, Minneapolis, MN, USA). The electrodes were attached to an EI400 potentiostat (Ensman Instrumentation, Bloomington, IN, USA). Recordings were undertaken with a fixed voltage $(0.6 \mathrm{~V}$ amperometric mode) against an $\mathrm{AgCl}$ reference electrode. This voltage is optimum for measuring norepinephrine and epinephrine (the main catecholamine contained in mice adrenal medulla), as was demonstrated by the HPLC-ED measurements of the catecholamine content in mice adrenal medulla. Currents corresponding to free catecholamine measurements were sampled at $4 \mathrm{~Hz}$, recorded by computer (Data sponge, WPI Instruments, Sarasota, FL, USA) and later analyzed offline (Microcal Origin, Northampton, MA, USA).


FIG. 1. Effects of ciclopiazonic acid on catecholamine secretion and $\left[\mathrm{Ca}^{2+}\right]_{\mathrm{c}}$ increase induced by high $\mathrm{K}^{+}$. In panel $\mathrm{A}$, catecholamine secretion induced by either $5 \mathrm{~s}$ or $10 \mathrm{~s}$ pulses (marked by $\boldsymbol{\Delta}$ or symbols at the bottom) of medium containing $35 \mathrm{mM} \mathrm{KCl}$ was measured in a whole mouse adrenal medulla. When indicated, $10 \mu \mathrm{M}$ ciclopiazonic acid (CPA) was perfused. In panel $\mathrm{B},\left[\mathrm{Ca}^{2+}\right]_{\mathrm{c}}$ peaks induced by $10 \mathrm{~s}$ pulses $(-)$ of medium containing $35 \mathrm{mM} \mathrm{KCl}$ were measured in dissociated mouse chromaffin cells expressing cytosolic aequorin. When indicated, $10 \mu \mathrm{M} \mathrm{CPA}$ was perfused.

Tissues were impaled with a single $5-\mu \mathrm{m}$ carbon fibre under microscope. After a variable period (60-90 $\mathrm{min}$ ) of superfusion in control conditions, the amperometric recordings became stable and preparations were subjected to different experimental protocols, as detailed in the Results section. In most cases, prior to recording from the tissues the carbon fibre electrode was advanced into the bath chamber and calibrated by switching between Tyrode solution with or without $10 \mu \mathrm{M}$ epinephrine. At the end of the experiment, the electrode was withdrawn from the tissue and calibrated again. Comparison of the calibration before and following the study was used to assess whether the electrode sensitivity changed over the recording period. As caffeine was used at high concentration (5 mM), the possible effect of the drug on our amperometric recording system was checked. It was found that caffeine, under our conditions, neither generates any signal nor interferes in the measurement of the catecholamine secretory response.

Measurements of $\left[\mathrm{Ca}^{2+}\right]_{\mathrm{c}}$ and $\left[\mathrm{Ca}^{2+}\right]_{\mathrm{ER}}$. Decapsulated adrenal glands were dissociated as described previously (Hernández-Guijo et al., 1998) by incubation for $40 \mathrm{~min}$ at $37^{\circ} \mathrm{C}$ in Locke's medium $\left(154 \mathrm{~mm} \mathrm{NaCl}, 5.6 \mathrm{~mm} \mathrm{KCl} ; 3.6 \mathrm{mM} \mathrm{NaHCO}_{3} ; 5.6 \mathrm{~mm}\right.$ glucose, $10 \mathrm{~mm}$ Hepes, pH 7.2) containing $1.3 \mathrm{mg} / \mathrm{mL}$ collagenase (Hoffmann-La Roche, Basel, Switzerland) and $3 \mathrm{mg} / \mathrm{mL}$ bovine serum albumin, with gentle periodic agitation. The suspension was centrifuged for $10 \mathrm{~min}$ at $100 \times g$ and resuspended in Locke's medium. Cells were then plated onto $13 \mathrm{~mm}$ glass poly D-lysine- 

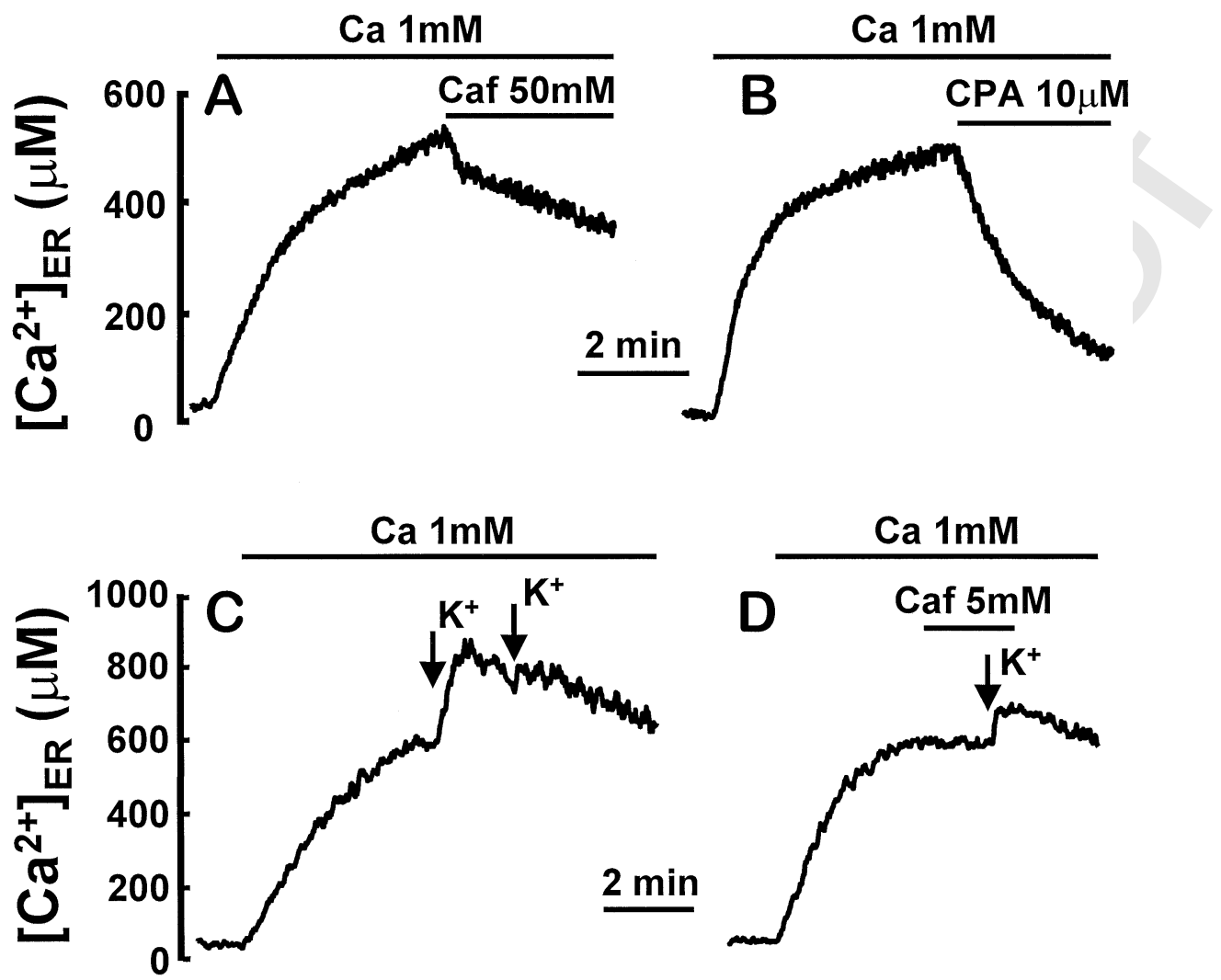

FIG. 2. Effect of caffeine, $\mathrm{CPA}$ and high $\mathrm{K}^{+}$on $\left[\mathrm{Ca}^{2+}\right]_{\mathrm{ER}}$. Dissociated mouse chromaffin cells expressing ER-targeted aequorin were depleted of $\mathrm{Ca}^{2+}$ and reconstituted with coelenterazine $\mathrm{n}$. Then, when indicated in the panels, medium containing $1 \mathrm{mM} \mathrm{Ca}^{2+}$ was perfused to refill the ER with Ca ${ }^{2+}$. Once $\left[\mathrm{Ca}^{2+}\right]_{\mathrm{ER}}$ was almost at the steady-state level, either $50 \mathrm{mM}$ caffeine (panel A), $10 \mu \mathrm{M} \mathrm{CPA}$ (panel B), $10 \mathrm{~s}$ pulses of medium containing $70 \mathrm{~mm} \mathrm{KCl}$ (panels $\mathrm{C}$ and $\mathrm{D}$ ) or $5 \mathrm{~mm}$ caffeine (panel D) were perfused as indicated.

coated coverslips and cultured in Dulbecco's modified Eagle's medium (DMEM) supplemented with 5\% foetal calf serum, $50 \mathrm{IU} /$ $\mathrm{mL}$ penicillin and $50 \mu \mathrm{g} / \mathrm{mL}$ streptomycin. After allowing $6 \mathrm{~h}$ for complete cell attachment, they were infected with defective herpes simplex viruses type 1 carrying the corresponding construct for either the cytosolic- or the ER-targeted aequorin chimera. Preparation of mutated aequorin targeted to the endoplasmic reticulum has been described before (Montero et al., 1995). Cytosolic aequorin cDNA was obtained from Molecular Probes and cloned in the pHSVpUC plasmid. Virus packaging and titreing have been previously described (Alonso et al., 1998). Chromaffin cell cultures were routinely infected with $2 \times 10^{3}$ infectious virus units $12-24 \mathrm{~h}$ prior to measurements.

For aequorin reconstitution, cells expressing wild-type aequorin targeted to the cytosol were incubated for $1-2 \mathrm{~h}$ at room temperature with $1 \mu \mathrm{M}$ of wild-type coelenterazine in medium containing $145 \mathrm{~mm}$ $\mathrm{NaCl}, 5 \mathrm{mM} \mathrm{KCl}, 1 \mathrm{mM} \mathrm{MgCl}_{2}, 1 \mathrm{mM} \mathrm{CaCl}_{2}, 10 \mathrm{~mm}$ glucose, and $10 \mathrm{mM}$ HEPES, pH 7.4. Cells were then placed in the perfusion chamber of a purpose-built luminometer thermostatized at $37{ }^{\circ} \mathrm{C}$. In the case of aequorin targeted to the ER, $\mathrm{Ca}^{2+}$ depletion of the ER was required prior to reconstitution. For this purpose, cells were incubated for $10 \mathrm{~min}$ in medium containing $145 \mathrm{~mm} \mathrm{NaCl}, 5 \mathrm{~mm} \mathrm{KCl}, 1 \mathrm{mM}$ $\mathrm{MgCl}_{2}, 0.5 \mathrm{mM}$ EGTA, $10 \mu \mathrm{M}$ 2,5-di-tert-buthyl-hydroquinone (an inhibitor of ER $\mathrm{Ca}^{2+}$ ATPase), $10 \mathrm{~mm}$ glucose, and $10 \mathrm{mM}$ HEPES, $\mathrm{pH}$ 7.4. Then, after washing once, cells were placed in the same medium in the presence of $1 \mu \mathrm{M}$ coelenterazine $\mathrm{n}$ for $1-2 \mathrm{~h}$. Before starting the experiment, cells were placed in the perfusion chamber of a luminometer (composed of a 9789-A photomultiplier connected through an amplifier-discriminator AD 2 to a PCB CT1 card in the computer, all components from Electron Tubes, Ruislip, UK) and perfused with the same medium without 2,5-di-tert-buthyl-hydroquinone for at least $5 \mathrm{~min}$. Experiments with ER-targeted aequorin were performed at $22{ }^{\circ} \mathrm{C}$ to reduce the rate of aequorin consumption.

\section{Materials}

Wild-type coelenterazine and coelenterazine $\mathrm{n}$ were obtained from Molecular Probes Europe BV, Leiden, The Netherlands. Ciclopiazonic acid and ryanodine were from Sigma, Madrid. Thapsigargin was from Alomone Laboratories, Israel. Other reagents were from Sigma, Madrid or Merck, Darmstadt.

\section{Results}

Characterization of the superfused in vitro preparation of mice adrenal medulla

A new in vitro superfused preparation of adrenal medulla from mice is reported in this work. This preparation is useful to study the secretion of catecholamines from the adrenal medulla as it is easy to obtain and allows monitoring the secretory responses evoked by different stimuli in the intact organ with a good time resolution. Recordings of the catecholamine efflux from the glands were initiated after a 60-90-min period to allow stabilization of the preparation. As shown below, the responses evoked by short pulses (5-10 s) of depolarizing stimuli were quite fast, had a short latency and remained constant without significant attenuation for several hours. Another aspect that we have characterized in our preparation was the content 


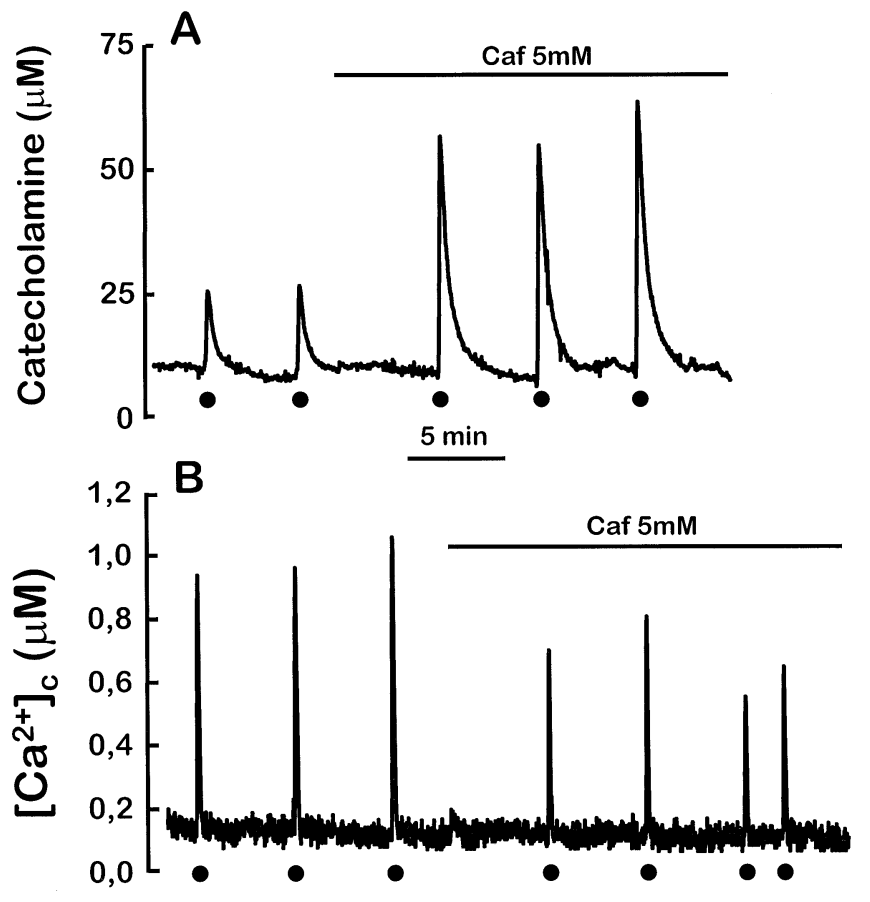

FIG. 3. Effects of $5 \mathrm{~mm}$ caffeine on high- $\mathrm{K}^{+}$-induced catecholamine secretion and $\left[\mathrm{Ca}^{2+}\right]_{\mathrm{c}}$ peaks. Panel A shows a record of catecholamine secretion obtained from a whole mouse adrenal medulla. Secretion was stimulated by pulses of $7 \mathrm{~s}$ of medium containing $35 \mathrm{mM} \mathrm{KCl}(\mathbf{)})$. When indicated, $5 \mathrm{~mm}$ caffeine ('Caf $5 \mathrm{~mm}$ ') was perfused. Panel B shows a record of $\left[\mathrm{Ca}^{2+}\right]_{\mathrm{c}}$ in dissociated mouse chromaffin cells expressing cytosolic aequorin. Cells were stimulated by $5 \mathrm{~s}$ pulses of medium containing $35 \mathrm{~mm}$ $\mathrm{KCl}(-)$. When indicated, $5 \mathrm{~mm}$ caffeine was perfused ('Caf $5 \mathrm{~mm}$ ').

of catecholamines. Using HPLC-ED, the values obtained from these measurements, expressed in nmol/gland (mean \pm SEM, $n=6$ ), were $1.08 \pm 0.30,2.16 \pm 0.65$ and $0.60 \pm 0.10$ for norepinephrine, epinephrine and dopamine, respectively. These results are quite similar to those previously reported by other authors (Bornstein et al., 1999; Bland et al., 2000). All of these properties make the in vitro preparation of adrenal medulla from mice a good model to study the modulation of the release response evoked by different stimuli.

\section{Cyclopiazonic acid potentiates both secretion and $\left[\mathrm{Ca}^{2+}\right]_{c}$ peaks evoked by high-K $K^{+}$}

Using the preparation described above, we have first studied the contribution of calcium stores to the catecholamine release response evoked by depolarizing stimuli. First, we emptied the ER-Ca ${ }^{2+}$ store by inhibiting the sarco-endoplasmic reticulum $\mathrm{Ca}^{2+}$ ATPase (SERCA) with cyclopiazonic acid (CPA). In this way both CICR and $\mathrm{Ca}^{2+}$ uptake by the ER were abolished. Figure 1a shows that perfusion of CPA $10 \mu \mathrm{M}$ modified little the resting catecholamine release but produced a large increase in the secretory response evoked when 5 or $10 \mathrm{~s}$ pulses of medium containing $35 \mathrm{mM} \mathrm{KCl}$ were applied. The release responses were increased to $148 \pm 5 \%$ of the control value (mean \pm SEM, $n=9$ ) when $10 \mathrm{~s}$ depolarizing pulses were used and much more ( $273 \pm 36 \%$, mean \pm SEM, $n=6)$ for shorter depolarizing pulses. This effect was not due to saturation of the secretory response, as stronger stimulation (i.e. $60 \mathrm{mM} \mathrm{K}^{+}, 10 \mathrm{~s}$ ) produced a much larger secretion peak (up to 6-fold higher). The same effects were obtained using thapsigargin to empty the ER of $\mathrm{Ca}^{2+}$ (Fig. 4a). These results suggest that CICR is not functional in these cells and that the ER behaves more as a sink of $\mathrm{Ca}^{2+}$ than as a

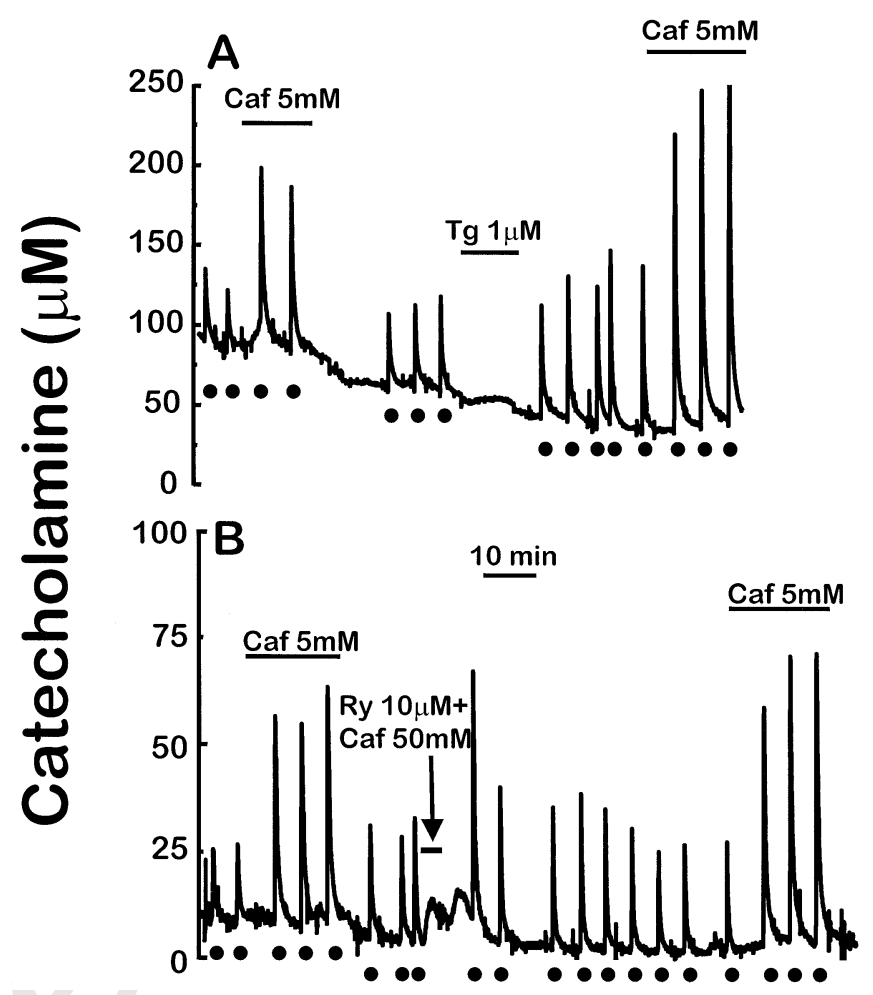

FIG. 4. Efects of caffeine, thapsigargin and ryanodine on high- $\mathrm{K}^{+}$-induced catecholamine secretion. The figure shows catecholamine secretion records obtained from whole mouse adrenal medulla. Secretion was stimulated by either $10 \mathrm{~s}$ (panel A) or $7 \mathrm{~s}$ (panel B) pulses of medium containing $35 \mathrm{~mm}$ $\mathrm{KCl}(\bullet)$. When indicated, either $5 \mathrm{mM}$ caffeine ('Caf $5 \mathrm{~mm}$ '), $1 \mu \mathrm{M}$ thapsigargin ('Tg $1 \mu \mathrm{M}$ ') or $10 \mu \mathrm{M}$ ryanodine $+50 \mathrm{mM}$ caffeine ('Ry $10 \mu \mathrm{M}+$ Caf $50 \mathrm{~mm}$ ') were perfused.

source under resting conditions (with the ER full of $\mathrm{Ca}^{2+}$ ). If this is the case, inhibition of $\mathrm{Ca}^{2+}$ pumping to the ER would be expected to increase the $\left[\mathrm{Ca}^{2+}\right]_{\mathrm{c}}$ levels obtained after the depolarizing stimulus. Figure $1 \mathrm{~b}$ shows that this was the case. Perfusion of CPA produced a small increase in the resting $\left[\mathrm{Ca}^{2+}\right]_{\mathrm{c}}$ level, from $102 \pm 6 \mathrm{nM}$ to $157 \pm 15 \mathrm{nM}($ mean $\pm \mathrm{SEM}, n=7)$, but considerably increased the $\left[\mathrm{Ca}^{2+}\right]_{\mathrm{c}}$ peaks induced by high- $\mathrm{K}^{+}$treatment. In several similar experiments, high- $\mathrm{K}^{+}$-induced $\left[\mathrm{Ca}^{2+}\right]_{\mathrm{c}}$ peaks were increased to $150 \pm 14 \%$ (mean $\pm \mathrm{SEM}, n=9$ ) of the control value in the presence of CPA.

\section{Absence of CICR induced by high- $\mathrm{K}^{+}$and poor $\mathrm{Ca}^{2+}$ release response to caffeine}

Another pharmacological manoeuvre usually employed to activated RyR is caffeine. In bovine chromaffin cells, stimulation with $50 \mathrm{mM}$ caffeine produces a very fast and full emptying of the ER $\left(t_{\frac{1}{2}}<10 \mathrm{~s}\right.$, Alonso et al., 1999), and a significant release response (Montero et al., 2000). Half-maximal effect was obtained with $5 \mathrm{~mm}$ caffeine, and lower concentrations (1-2 mM) produced little effect by themselves, but potentiated CICR induced by high- $\mathrm{K}^{+}$stimulation (Alonso et al., 1999). In contrast, $50 \mathrm{~mm}$ caffeine produced a very small $\mathrm{Ca}^{2+}$ release from the ER in mouse chromaffin cells. Figure 2a shows that $50 \mathrm{~mm}$ caffeine produced only a small initial $\mathrm{Ca}^{2+}$ release that reduced the $\left[\mathrm{Ca}^{2+}\right]_{\mathrm{ER}}$ by approximately $50 \mu \mathrm{M} \quad(50 \pm 7 \mu \mathrm{M}$, mean \pm SEM, $n=8$ ), followed by a much slower decrease in the $\mathrm{ER} \mathrm{Ca}^{2+}$ content. Consistently, $50 \mathrm{~mm}$ caffeine produced only a small secretory response (data not shown). Figure $2 \mathrm{~b}$ shows the effect of 
$\mathrm{CPA}$ on $\left[\mathrm{Ca}^{2+}\right]_{\mathrm{ER}}$ for comparison. Inhibiting SERCA produces a relatively slow release of $\mathrm{Ca}^{2+}$ from the ER, that was in this case much faster than that induced by caffeine, and complete. Given the poor effect of caffeine on ER-Ca ${ }^{2+}$ release, we expected that CICR could not be observed in these cells. Figure $2 \mathrm{c}$ shows that this was the case. In contrast to the results obtained in bovine chromaffin cells (Alonso et al., 1999), stimulation with high- $\mathrm{K}^{+}$of mouse chromaffin cells produced a rapid increase in $\left[\mathrm{Ca}^{2+}\right]_{\mathrm{ER}}$, probably because of the activation of SERCA after the high- $\mathrm{K}^{+}$-induced $\left[\mathrm{Ca}^{2+}\right]_{\mathrm{c}}$ increase. The presence of low concentrations of caffeine (2-5 mM) did not modify the effect of high $-\mathrm{K}^{+}$on $\left[\mathrm{Ca}^{2+}\right]_{\mathrm{ER}}$ (Fig. 2d). This panel shows also that a concentration of caffeine of $5 \mathrm{~mm}$, that produced a halfmaximal $\mathrm{Ca}^{2+}$ release response in bovine chromaffin cells (Alonso et al., 1999) had no effect on $\left[\mathrm{Ca}^{2+}\right]_{\mathrm{ER}}$ in mouse chromaffin cells.

\section{Caffeine potentiates the secretory response evoked by depolarizing stimuli by a mechanism unrelated to $\mathrm{ER}-\mathrm{Ca}^{2+}$ release}

The results of Figs 1 and 2 clearly suggest that CICR is not operative in mouse chromaffin cells. It was therefore a surprise to find that low concentrations of caffeine, which do not affect the basal catecholamine response, strongly potentiates the release response promoted by $35 \mathrm{~mm} \mathrm{KCl}$. Figure $3 \mathrm{a}$ shows that perfusion of $5 \mathrm{~mm}$ caffeine did not modify the secretory response by itself, but largely increased that induced by high- $\mathrm{K}^{+}$stimulation. In several similar experiments, high$\mathrm{K}^{+}$-evoked catecholamine secretion was increased to $224 \pm 15 \%$ (mean $\pm \mathrm{SEM}, n=12$ ) of the control value in the presence of $5 \mathrm{mM}$ caffeine. However, this effect was not due to an increase in the high$\mathrm{K}^{+}$-induced $\left[\mathrm{Ca}^{2+}\right]_{\mathrm{c}}$ peaks. Figure $3 \mathrm{~b}$ shows that, instead, the $\left[\mathrm{Ca}^{2+}\right]_{\mathrm{c}}$ transients induced by depolarization were reduced in the presence of caffeine $5 \mathrm{mM}$. In several similar experiments, $\left[\mathrm{Ca}^{2+}\right]_{\mathrm{c}}$ peaks evoked by high $-\mathrm{K}^{+}$in the presence of caffeine were reduced to $66 \pm 3 \%$ (mean $\pm \mathrm{SEM}, n=19$ ) with respect to the controls.

Further evidence in favour of the suggestion that the effect of caffeine was unrelated to CICR was obtained by studying its effect after emptying the ER of $\mathrm{Ca}^{2+}$. Figure 4 a shows that caffeine still potentiated secretion after full and irreversible depletion of $\mathrm{Ca}^{2+}$ from the ER. Taking advantage of the long period of time that the in vitro preparation of the mice adrenal medulla remains stable, we tested whether caffeine still potentiates the secretory response evoked by $10 \mathrm{~s}$ pulses of $35 \mathrm{mM} \mathrm{KCl}$ once the ER had been completely emptied of $\mathrm{Ca}^{2+}$ with $1 \mu \mathrm{M}$ thapsigargin, a powerful, selective and irreversible inhibitor of SERCA. In the experiment shown in Fig. 4a, the initial part demonstrates again the potentiation by caffeine of the secretory response evoked by $35 \mathrm{~mm} \mathrm{KCl}$. After washing away caffeine, the control secretory responses to high- $\mathrm{K}^{+}$stimulation were recovered. Then, a $5 \mathrm{~min}$ superfusion with thapsigargin was applied to irreversibly empty the ER of $\mathrm{Ca}^{2+}$. It can be observed that the responses to high- $\mathrm{K}^{+}$became potentiated after this treatment (to $166 \pm 13 \%$ of the control, mean \pm SEM, $n=6$ ), probably by the same mechanism that in the case of CPA (Fig. 1). Finally, perfusion of $5 \mathrm{~mm}$ caffeine strongly potentiated again the secretory responses to high- $\mathrm{K}^{+}$(to $269 \pm 27 \%$ of the response in the presence of thapsigargin, mean $\pm \mathrm{SEM}, n=6$ ). After treatment with thapsigargin, the response evoked by the depolarizing stimulus in the presence of caffeine was approximately the sum of the individual responses obtained in the presence of either thapsigargin alone or caffeine alone. The potentiating effect of caffeine was therefore additive to that of emptying the ER of $\mathrm{Ca}^{2+}$, indicating that it is not due to activation of CICR from the ER.

The presence of RyR in subcellular locations other than the ER is controversial. It has been suggested, for example, that RyR may be present in the membrane of the secretory vesicles, and that it may mediate $\mathrm{Ca}^{2+}$ release from the vesicle (Gerasimenko et al., 1996; Mitchell et al., 2001). In this way, these RyR could contribute to the release of the $\mathrm{Ca}^{2+}$ required for the secretion of that vesicle. To investigate if the effects of caffeine could be due to stimulation of RyR located outside the ER, we decided to use ryanodine to block RyR responses independently of its subcellular location. Figure $4 \mathrm{~b}$ shows a secretion experiment in which we first demonstrate the reversible potentiating effect of $5 \mathrm{~mm}$ caffeine. Once the high- $\mathrm{K}^{+}-$ induced secretory peaks had almost returned to the control levels, we superfused the mice adrenal medulla with ryanodine, the irreversible antagonist of ryanodine receptors. Ryanodine $(10 \mu \mathrm{M})$ was applied in the presence of high doses of caffeine to assure the irreversible antagonist effect of ryanodine that requires the channel to be open in order to block it (the so-called use-dependence of ryanodine, Cheek et al., 1994; Ehrlich et al., 1994; Alonso et al., 1999). A long period of washing was allowed after that, during which the response to high$\mathrm{K}^{+}$stimulation slowly decreased, probably as a result of the slow washing of the potentiating effect of caffeine. After that, perfusion of $5 \mathrm{~mm}$ caffeine increased again the secretory response evoked by the depolarizing stimulus. Overall, these results strongly argue against the involvement of RyR in the potentiation of secretion by caffeine. The actual mechanism of this potentiation may then rely on a different property of caffeine, e.g. the inhibition of phosphodiesterase. In fact, perfusion of $1 \mathrm{~mm}$ 3-isobutyl-1-methylxanthine, a compound that inhibits phosphodiesterase without activating RyR, stimulated secretion induced by high $-\mathrm{K}^{+}$to a similar extent as caffeine (data not shown).

\section{Discussion}

In this paper we provide new evidence for the involvement of the ER in the modulation of catecholamine secretion in chromaffin cells. Blocking $\mathrm{Ca}^{2+}$ pumping into the ER, either with CPA or with thapsigargin, produced a strong stimulation of catecholamine secretion, which was more evident when short high- $\mathrm{K}^{+}$stimulations were used. Consistently, high- $\mathrm{K}^{+}$stimulation produced a fast increase in $\left[\mathrm{Ca}^{2+}\right]_{\mathrm{ER}}$. These findings suggest that, after cell depolarization, the ER takes up a significant proportion of the $\mathrm{Ca}^{2+}$ entering the cell through voltage-operated $\mathrm{Ca}^{2+}$ channels, damping the secretory response. This modulation appears to be particularly important for stimuli of small intensity. This seems quite reasonable, because when the stimulus is too intense, the large increase in $\left[\mathrm{Ca}^{2+}\right]_{c}$ probably saturates $\mathrm{ER} \mathrm{Ca}^{2+}$ uptake, so that the amount of $\mathrm{Ca}^{2+}$ taken up by the ER becomes a small fraction of the total $\mathrm{Ca}^{2+}$ entry. Under these conditions, $\mathrm{Ca}^{2+}$ uptake by the ER cannot be effective to modulate secretion. Instead, $\mathrm{Ca}^{2+}$ uptake by the ER appears to be prepared to play a role in the control of secretion induced by low-intensity, more physiological, stimuli. In this case, ER regions close to the plasma membrane $\mathrm{Ca}^{2+}$ channels may be able to sequester a significant proportion of the $\mathrm{Ca}^{2+}$ entering the cell through those channels. Of course, $\mathrm{Ca}^{2+}$ uptake by the ER is not the only mechanism responsible of cytosolic $\mathrm{Ca}^{2+}$ clearance. Mitochondria and plasma membrane $\mathrm{Ca}^{2+}$ pump and $\mathrm{Na}^{+} / \mathrm{Ca}^{2+}$ exchange also contribute to damp the $\left[\mathrm{Ca}^{2+}\right]_{\mathrm{c}}$ signal. On the other hand, we should note that depletion of $\mathrm{Ca}^{2+}$ from the ER may have additional effects, such as activation of store-operated $\mathrm{Ca}^{2+}$ channels, which may contribute to the facilitation of exocytosis (Fomina et al., 1999). However, blocking ER-Ca ${ }^{2+}$ uptake with CPA or thapsigargin produced only a small and transient increase in $\left[\mathrm{Ca}^{2+}\right]_{\mathrm{c}}$. This suggests that the different $\mathrm{Ca}^{2+}$ clearance 
mechanisms rapidly extrude the $\mathrm{Ca}^{2+}$ released from the ER and also that store-operated $\mathrm{Ca}^{2+}$ channels are not very active in these cells.

The absence of CICR and the small effect of caffeine on $\left[\mathrm{Ca}^{2+}\right]_{\mathrm{ER}}$ in mouse chromaffin cells suggest that these cells possess only a scarce number of functional RyR in the ER. This came as a surprise, given the high activity observed in bovine chromaffin cells (Alonso et al., 1999), where they clearly participate in CICR induced by high$\mathrm{K}^{+}$. Chromaffin cells obtained from 19 to 31-day-old-rats are also very sensitive to caffeine, both in terms of secretion and $\left[\mathrm{Ca}^{2+}\right]_{\mathrm{c}}$ response (Finnegan et al., 1996; Guo et al., 1996). Interestingly, cultures obtained from 10-day-old rats lack a significant response to caffeine, and only recover it after 15 days in culture in the presence of nerve growth factor, in parallel with an increased expression of RyR type 2 (Jiménez \& Hernández-Cruz, 2001). CICR appears therefore not to be an essential mechanism for the development of the secretory response in chromaffin cells, although it may have physiological significance when it is present. Regarding the modulation by $\mathrm{ER} \mathrm{Ca}^{2+}$ uptake, depletion of $\mathrm{Ca}^{2+}$ from the ER in bovine chromaffin cells produced little effect (or perhaps a slight enhancement) on the secretory response induced by high- $\mathrm{K}^{+}$(Cuchillo-Ibáñez et al., 2002), but reduced secretion induced by cell depolarization (Pan \& Fox, 2000) and that induced by activation of nicotinic receptors (Mollard et al., 1995; Cuchillo-Ibáñez et al., 2002). Perhaps the mixture of ER-Ca ${ }^{2+}$ uptake and CICR in these cells may produce compensating effects, that could be variable depending on the stimulus and even heterogeneous at the single-cell level. This could also explain the controversial findings mentioned above. In the mouse, the absence of CICR helps to observe uncontaminated the effects of ER-Ca ${ }^{2+}$ uptake on the secretory response. We should mention also that inositol 1,4,5-trisphosphate receptors might participate as well in CICR phenomena. Mouse chromaffin cells possess this kind of receptors, which can be activated by agonists such as carbachol producing large $\left[\mathrm{Ca}^{2+}\right]_{\mathrm{c}}$ peaks $(1.70 \pm 0.14 \mu \mathrm{M}$, mean $\pm \mathrm{SEM}, n=6)$. However, this response requires the presence of inositol 1,4,5-trisphosphate, and is not expected to occur after high- $\mathrm{K}^{+}$stimulation.

In the absence of functional RyR in the ER, the potentiating effect of low caffeine concentrations on catecholamine secretion triggered by cell depolarization was puzzling. This effect persisted after full ER-Ca ${ }^{2+}$ depletion with thapsigargin and also after treatment with ryanodine. Therefore, we can conclude that RyR are not involved in that potentiation. Additional effects of caffeine, such as phosphodiesterase inhibition and the subsequent increase of cyclic nucleotide levels, may be responsible for the enhancement of the secretory response. Potentiation of catecholamine secretion by an increase in the levels of cyclic nucleotides has been reported previously (Morita et al., 1985; Starke et al., 1989), and our finding that an inhibitor of phosphodiesterase, 3-isobutyl-1-methylxanthine, stimulates secretion similarly to caffeine, argues also in favour of this hypothesis. On the other hand, the reduction observed in the size of the high- $\mathrm{K}^{+}$-induced $\left[\mathrm{Ca}^{2+}\right]_{\mathrm{c}}$ peaks in the presence of caffeine may be attributed to the inhibition of voltage-operated $\mathrm{Ca}^{2+}$ channels by this compound (Villalobos \& García-Sancho, 1996). Moreover, these findings indicate that the effects of caffeine should not be taken as unequivocally due to activation of RyR or as an equivalent of CICR.

The differential behaviour regarding CICR of mouse and bovine chromaffin cells is rather surprising. It has been reported previously that chromaffin cells from different species (cow, pig, cat, rat or mouse) show large differences in the relative expression of plasma membrane high-threshold $\mathrm{Ca}^{2+}$ channel subtypes (Hernández-Guijo et al., 1998). We show here that extreme differences (all-or-none) in expression among different species can also be found regarding intracellular $\mathrm{Ca}^{2+}$ channels. Knowledge of these properties of mouse chromaffin cells is interesting, because of the possibility of generating transgenic mice to study specific problems of $\mathrm{Ca}^{2+}$ homeostasis and secretion. On the other hand, interspecies differences observed in this study raise questions as to the physiological importance of mechanisms such as CICR on the secretory response of adrenal cells, if it is not observed in all species.

\section{Acknowledgements}

Financial support from Ministerio de Ciencia y Tecnología (BFI2002/01397) and Junta de Castilla y León (VA 005/02) to JA, and from Fondo de Investigaciones Sanitarias (FIS 01/0728) and Junta de Castilla y León (VA 46/ 00B) to RR are gratefully acknowledged. We thank David Donnelly for helpful discussions and comments on the manuscript.

\section{Abbreviations}

$\left[\mathrm{Ca}^{2+}\right]_{\mathrm{c}}$, cytosolic $\left[\mathrm{Ca}^{2+}\right] ;\left[\mathrm{Ca}^{2+}\right]_{\mathrm{ER}}$, endoplasmic reticulum $\left[\mathrm{Ca}^{2+}\right]$; ER, endoplasmic reticulum; CICR, $\mathrm{Ca}^{2+}$ induced $\mathrm{Ca}^{2+}$ release; RyR, ryanodine receptors; SERCA, sarcoendoplasmic reticulum $\mathrm{Ca}^{2+}$ ATPase; CPA, ciclopiazonic acid; DMEM, Dulbecco's modified Eagle medium; HPLC-ED, highperformance liquid chromatography-electrochemical detection.

\section{References}

Alonso, M.T., Barrero, M.J., Carnicero, E., Montero, M., García-Sancho, J. \& Alvarez, J. (1998) Functional measurements of $\left[\mathrm{Ca}^{2+}\right]$ in the endoplasmic reticulum using a herpes virus to deliver targeted aequorin. Cell Calcium, 24, 87-96.

Alonso, M.T., Barrero, M.J., Michelena, P., Carnicero, E., Cuchillo, I., García, A.G., García-Sancho, J., Montero, M. \& Alvarez, J. (1999) $\mathrm{Ca}^{2+}$-induced $\mathrm{Ca}^{2+}$ release in chromaffin cells seen from inside the ER with targeted aequorin. J. Cell Biol., 144, 241-254.

Berridge, M.J. (1998) Neuronal calcium signalling. Neuron, 21, 13-26.

Bland, M.L., Jamieson, C.A., Akana, S.F., Bornstein, S.R., Eisenhofer, G., Dallman, M.F. \& Ingraham, H.A. (2000) Haploinsufficiency of steroidogenic factor-1 in mice disrupts adrenal development leading to an impaired stress response. Proc. Natl. Acad. Sci. USA, 97, 14488-14493.

Bornstein, S.R., Tajima, T., Eisenhofer, G., Haidan, A. \& Aguilera, G. (1999) Adrenomedullary function is severely impaired in 21-hydroxylase-deficient mice. FASEB J., 13, 1185-1194.

Carter, A.G., Vogt, K.E., Foster, K.A. \& Regehr, W.G. (2002) Assessing the role of calcium-induced calcium release in short-term presynaptic plasticity at excitatory central synapses. J. Neurosci., 22, 21-28.

Cheek, T.R., Berridge, M.J., Moreton, R.B., Stauderman, K.A., Murawsky, M.M. \& Bootman, M.D. (1994) Quantal $\mathrm{Ca}^{2+}$ mobilization by ryanodine receptors is due to all-or-none release from functionally discrete intracellular stores. Biochem. J., 301, 879-883.

Cuchillo-Ibáñez, I., Olivares, R., Aldea, M., Villarroya, M., Arroyo, G., Fuentealba, J., García, A.G. \& Albillos, A. (2002) Acetylcholine and potassium elicit different patterns of exocytosis in chromaffin cells when the intracellular calcium handling is disturbed. Pflügers Arch., in press.

Ehrlich, B.E., Kaftan, E., Bezprozvannaya, S. \& Bezprozvanny, I. (1994) The pharmacology of intracellular $\mathrm{Ca}^{2+}$-release channels. Trends Pharmacol. Sci., 15, 145-149.

Emptage, N.J., Reid. C.A. \& Fine. A. (2001) Calcium stores in hippocampal synaptic boutons mediate short-term plasticity, store-operated $\mathrm{Ca}^{2+}$ entry, and spontaneous transmitter release. Neuron, 29, 197-208.

Faure, A.V., Grunwald, D., Moutin, M.J., Hilly, M., Mauger, J.P., Marty, I., De Waard, M., Villaz, M. \& Albrieux, M. (2001) Developmental expression of the calcium release channels during early neurogenesis of the mouse cerebral cortex. Eur. J. Neurosci., 14, 1613-1622.

Finnegan, J.M., Borges, R. \& Wightman, R.M. (1996) Comparison of cytosolic $\mathrm{Ca}^{2+}$ and exocytosis responses from single rat and bovine chromaffin cells. Neuroscience, 71, 833-843.

Fomina, A.F. \& Nowycky, M.C. (1999) A current activated on depletion of intracellular $\mathrm{Ca}^{2+}$ stores can regulate exocytosis in adrenal chromaffin cells. J. Neurosci., 19, 3711-3722.

Gerasimenko, O.V., Gerasimenko, J.V., Belan, P.V. \& Petersen, O.H. (1996) 
Inositol trisphosphate and cyclic ADP-ribose-mediated release of $\mathrm{Ca}^{2+}$ from single isolated pancreatic zymogen granules. Cell, 84, 473-480.

Giannini, G., Conti, A., Mammarella, S., Scrobogna, M. \& Sorrentino, V. (1995) The ryanodine receptor/calcium channel genes are widely and differentially expressed in murine brain and peripheral tissues. J. Cell Biol., 128, 893-904.

Guo, X., Przywara, D.A., Wakade, T.D. \& Wakade, A.R. (1996) Exocytosis coupled to mobilization of intracellular calcium by muscarine and caffeine in rat chromaffin cells. J. Neurochem., 67, 155-162.

Hernández-Guijo, J.M., Pascual, R., García, A.G. \& Gandía, L. (1998) Separation of calcium channel current components in mouse chromaffin cells superfused with low- and high-barium solutions. Pflügers Arch., 436, $75-82$.

Jimenez, N. \& Hernández-Cruz, A. (2001) Modifications of intracellular $\mathrm{Ca}^{2+}$ signalling during nerve growth factor-induced neuronal differentiation of rat adrenal chromaffin cells. Eur. J. Neurosci., 13, 1487-1500.

Karhapaa, L. \& Tornquist, K. (1997) Effects of caffeine on the influx of Q4 extracellular calcium in GH4C1 pituitary cells. J. Cell Physiol., 171, 52-60.

Krizaj, D., Bao, J.X., Schmitz, Y., Witkovsky, P. \& Copenhagen, D.R. (1999) Caffeine-sensitive calcium stores regulate synaptic transmission from retinal rod photoreceptors. J. Neurosci., 19, 7249-7261.

Lara, B., Lopez, M.G., Villarroya, M., Gandia, L., Cleeman, L., Morad, M. \& Garcia, A.G. (1997) A caffeine-sensitive $\mathrm{Ca}^{2+}$ store modulates $\mathrm{K}^{+}$-evoked secretion in chromaffin cells. Am. J. Physiol., 272, C1211-C1221.

Llano, I., Gonzalez, J., Caputo, C., Lai, F.A., Blayney, L.M., Tan, Y.P. \& Marty, A. (2000) Presynaptic calcium stores underlie large-amplitude miniature IPSCs and spontaneous calcium transients. Nature Neurosci., 3, $1256-1265$

Mackrill, J.J., Challiss, R.J., O'Connell, D.A., Lai, F.A. \& Nahorski, S.R. (1997) Differential expression and regulation of ryanodine receptor and myo-inositol 1,4,5-trisphosphate receptor $\mathrm{Ca}^{2+}$ release channels in mammalian tissues and cell lines. Biochem. J., 327, 251-258.

Martin, C., Chapman, K.E., Seckl, J.R. \& Ashley, R.H. (1998) Partial cloning and differential expression of ryanodine receptor/calcium-release channel genes in human tissues including the hippocampus and cerebellum. Neuroscience, 85, 205-216.

McPherson, P.S. \& Campbell, K.P. (1993) Characterization of the major brain form of the ryanodine receptor/ $\mathrm{Ca}^{2+}$ release channel. J. Biol. Chem., 268 , 19785-19790.

Mitchell, K.J., Pinton, P., Varadi, A., Tacchetti, C., Ainscow, E.K., Pozzan, T., Rizzuto, R. \& Rutter, G.A. (2001) Dense core secretory vesicles revealed as a dynamic $\mathrm{Ca}^{2+}$ store in neuroendocrine cells with a vesicle-associated membrane protein aequorin chimaera. J. Cell Biol., 155, 41-51.

Mollard, P., Seward, E. \& Nowycky, M.C. (1995) Activation of nicotinic receptors triggers exocytosis from bovine chromaffin cells in the absence of membrane depolarization. Proc. Natl. Acad. Sci. USA, 92, 3065-3069.

Montero, M., Alonso, M.T., Carnicero, E., Cuchillo-Ibáñez, I., Albillos, A.,
García, A.G., García-Sancho, J. \& Alvarez, J. (2000) Chromaffin-cell stimulation triggers fast millimolar mitochondrial $\mathrm{Ca}^{2+}$ transients that modulate secretion. Nature Cell Biol., 2, 57-61.

Montero, M., Brini, M., Marsault, R., Alvarez, J., Sitia, R., Pozzan, T. \& Rizzuto, R. (1995) Monitoring dynamic changes in free $\mathrm{Ca}^{2+}$ concentration in the endoplasmic reticulum of intact cells. EMBO J., 14, 5467-5475.

Mori. F., Fuyaka, M., Abe, H., Wakabayashi, K. \& Watanabe, M. (2000) Developmental changes in expression of the three ryanodine receptor mRNAs in the mouse brain. Neurosci. Lett., 285, 57-60.

Morita, K., Dohi, T., Kitayama, S. \& Tsujimoto, A. (1985) Enhancement of acetylcholine-evoked catecholamine release from perfused dog adrenals by elevating cyclic AMP levels.

Mothet, J.P., Fossier, P., Meunier, F.M., Stinnakre, J., Tauc, L. \& Baux, G. (1998) Cyclic ADP-ribose and calcium-induced calcium release regulate neurotransmitter release at a cholinergic synapse of Aplysia. J. Physiol., 507, 405-414.

Narita, K., Akita, T., Hachisuka, J., Huang, S., Ochi, K. \& Kuba, K. (2000) Functional coupling of $\mathrm{Ca}^{2+}$ channels to ryanodine receptors at presynaptic terminals. Amplification of exocytosis and plasticity. J. General Physiol., 115, 519-532.

Narita, K., Akita, T., Osanai, M., Shirasaki, T., Kijima, H. \& Kuba, K. (1998) A $\mathrm{Ca}^{2+}$-induced $\mathrm{Ca}^{2+}$ release mechanism involved in asynchronous exocytosis at frog motor nerve terminals. J. General Physiol., 112, 593-609.

Pan, C.Y. \& Fox, A.P. (2000) Rundown of secretion after depletion of intracellular calcium stores in bovine adrenal chromaffin cells. $J$. Neurochem., 75, 1132-1139.

Peng, Y. (1996) Ryanodine-sensitive component of calcium transients evoked by nerve firing at presynaptic nerve terminals. J. Neurosci., 16, 6703-6712.

Rose, C.R. \& Konnerth, A. (2001) Stores not just for storage. Intracellular calcium release and synaptic plasticity. Neuron, 31, 519-522.

Smith, A.B. \& Cunnane, T.C. (1996) Ryanodine-sensitive calcium stores involved in neurotransmitter release from sympathetic nerve terminals of the guinea-pig. J. Physiol., 497, 657-664.

Sorrentino, V. \& Volpe, P. (1993) Ryanodine receptors: how many, where and why? Trends Pharmacol. Sci., 14, 98-103.

Starke, K., Göthert, M. \& Kilbinger, H. (1989) Modulation of neurotransmitter release by presynaptic autoreceptors. Physiol. Rev., 69, 864-989.

Sutko, J.L. \& Airey, J.A. (1996) Ryanodine receptor $\mathrm{Ca}^{2+}$ release channels: does diversity in form equal diversity in function? Physiol. Rev., 76, 10271071

Villalobos, C. \& García-Sancho, J. (1996) Caffeine-induced oscillations of cytosolic $\mathrm{Ca}^{2+}$ in $\mathrm{GH}_{3}$ pituitary cells are not due to $\mathrm{Ca}^{2+}$ release from intracellular stores but to enhanced $\mathrm{Ca}^{2+}$ influx through voltage-gated $\mathrm{Ca}^{2+}$ channels. Pflügers Arch., 431, 371-378.

Zucchi, R. \& Ronca-Testoni, S. (1997) The sarcoplasmic reticulum $\mathrm{Ca}^{2+}$ channel/ryanodine receptor: modulation by endogenous effectors, drugs and disease states. Pharmacol. Rev., 49, 1-51. 


\section{Author Query Form}

Journal: European Journal of Neuroscience

Article: ejn2244

Dear Author,

During the preparation of your manuscript for publication, the questions listed below have arisen. The numbers pertain to the numbers in the margin of the proof. Please attend to these matters and return the form with this proof.

Many thanks for your assistance.

\begin{tabular}{|l|l|l|}
\hline $\begin{array}{l}\text { Query } \\
\text { Refs. }\end{array}$ & Query & Remarks \\
\hline Q1 & $\begin{array}{l}\text { Pan et al. 2000 has been changed to } \\
\text { Pan \& Fox 2000 so that this citation } \\
\text { matches the list }\end{array}$ & \\
\hline Q2 & $\begin{array}{l}\text { Hernandez-Guijo et al. 1998 has been } \\
\text { changed to Hernández-Guijo et al. } \\
\text { 1998 so that this citation matches the } \\
\text { list }\end{array}$ & \\
\hline Q3 & $\begin{array}{l}\text { Fomina \& Nowycky 1999 has been } \\
\text { changed to Fomina et al. 1999 so that } \\
\text { this citation matches the list }\end{array}$ & \\
\hline Q4 & $\begin{array}{l}\text { Karhapaa \& Tornquist 1997 has not } \\
\text { been found in the text }\end{array}$ & \\
\hline Q5 & $\begin{array}{l}\text { Krizaj et al. 1999 has not been found } \\
\text { in the text }\end{array}$ & \\
\hline Q6 & $\begin{array}{l}\text { Please supply journal, volume number } \\
\text { and page numbers }\end{array}$ & \\
\hline
\end{tabular}

